\title{
高次精度移流解法（WENO法）を用いた 津波による港湾内の地形変化に関する数値計算
}

\author{
梶川 勇樹 1 黒岩 正光 ${ }^{2}$-中山 仁成 3 \\ 1正会員 鳥取大学大学院助教 工学研究科社会基盤工学専攻（ $\bar{T} 680-8552$ 鳥取県鳥取市湖山町4丁目 101） \\ E-mail: kajikawa@cv.tottori-u.ac.jp \\ 2 正会員 鳥取大学大学院教授 工学研究科社会基盤工学専攻（= $680-8552$ 鳥取県鳥取市湖山町4丁目 101) \\ E-mail: kuroiwa@cv.tottori-u.ac.jp \\ 3非会員（株)エイト日本技術開発（†700-8617 岡山県岡山市北区津島京町3丁目1-21）
}

\begin{abstract}
本研究では, 津波襲来時の地形変化を高精度に予測できる数值計算モデルの開発を目的とし, 非線形長 波方程式，流砂の連続式，および浮遊砂輸送方程式に5次精度WENO（Weighted Essentially Non-Oscillatory） 法を用いたモデルを開発した。基礎方程式には，デカルト座標系上で港湾等の複雑境界形状を表現するた めFAVOR（Fractional Area/Volume Obstacle Representation）法を導入した. 構築した数值モデルを津波に伴 う港湾内外の地形変化に関する水理模型実験および現地スケールの現象に適用し，その妥当性を検証した。 その結果, 水理模型実験について, 本モデルは固定床における流況および移動床における地形変化を良好 に再現できることが示された。一方, 現地スケールの現象については, 3次元的流況の発達する領域への 適用は困難であるものの, 狭窄部での縮流に伴う地形変化については再現可能であることが示された.
\end{abstract}

Key Words : numerical simulation, WENO scheme, FAVOR method, Tsunami, topography change

\section{1. はじめに}

津波襲来時の土砂移動に伴う地形変化は，洗掘による 港湾施設の損壞，土砂堆積による船舶の利用制限等，港 湾機能に甚大な被害を及ぼす，そのため，津波による土 砂移動・地形変化を定量的に予測することは防災上極め て重要である. 従来, このような津波による地形変化予 測に関し非常に数多くの研究がなされてきた．特に，津 波伝搬計算に非線形長波モデルを用いた研究例は数多い

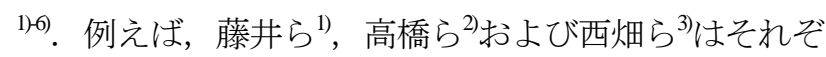
れ土砂移動モデルを提案するとともに，現地スケールの 現象を対象にモデルの適用性を検証している． Liら ${ }^{4}$ は， Xbeach土砂移動モデルロを津波による地形変化予測に適 用し，複数の津波シナリオによる現地スケールでの数值 実験を実施している、Sugawaraらのは，高橋らうによる土 砂移動モデルを採用し，2011年東北地方太平洋沖地震津 波による地形変化について検討を行っている，また，近 年では津波伝搬計算に静水圧近似による準3次元モデル7, さらには非静水圧を考慮した準3次元モデルがが提案され， 現地スケールでの地形変化予測に適用が進んでいる.

ところで，非線形長波モデルによる津波伝搬計算では, 従来, Tsunami-N29) ${ }^{9} \mathrm{COMCOT}^{10)}$ 等が広く用いられてきた. これらのモデルでは, 移流項の差分化に1次精度風上差 分法が採用されている. 1次精度風上差分法は安定した
計算が可能であるものの, 格子間隔が粗い場合, 数值粘 性により解が鈍り予測精度が低下寸る恐れがある，予測 精度の低下を避けるためには, 高次精度スキームの適用 が有効である ${ }^{11}$ 。近年，移流項の差分化にCIP法を用い た津波伝搬モデル ${ }^{8,12}$ が提案されているが，本研究では， WENO法 （Weighted Essentially Non-Oscillatory scheme） 11,13) を用いたモデルを提案する．WENO法は高次精度不連続 捕獲スキームの1つであり, CIP法と同様, 高次の人工粘 性項を必要としなくても不連続部を有する流れを安定的 かつ高精度に解析できる特徵を持つ. 従って, WENO法 の適用により，津波の伝搬から常射流が混在する汇濫流 まで高精度かつ高解像度で予測できる可能性がある.

従来，WENO法を用いた非線形長波モデルによる津波 伝搬計算例として, Li and Raichlen ${ }^{13)}$ による孤立波一の適

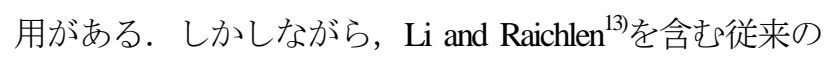
検討は実験室規模への適用に留まっており，また，津波 による地形変化にまでWENO法を適用した例は未だ無い．

以上より, 本研究では, 5次精度WENO法を用いた津 波伝搬計算および地形変化モデルを提案する. 構築した モデルを，藤井ら ${ }^{14} に$ にって行われた津波に伴う港湾内 地形変化に関する水理模型実験, および2011年東北地方 太平洋沖地震津波に伴う宮城県名取市䦥上漁港における 地形変化 ${ }^{15}$ に適用し，モデルの妥当性および適用性につ いて検討したものである. 


\section{2. 数値計算モデルの概要}

\section{(1) 津波伝搬計算の基礎方程式}

津波の数值計算には，非線形長波理論に基づく平面2 次元浅水流方程式を使用した. 座標系にはデカルト座標 系を採用し，等間隔格子上において港湾等の複雑境界形 状を表現するため，基礎方程式にはFAVOR法（Fractional Area/Volume Obstacle Representation method） ${ }^{10-19}$ を導入した. FAVOR法では，図-1に示寸ように，1つの格子において 流体と境界部が混在すると考え, 流体の占める体積率 $V$, および各軸方向に垂直な断面で流体が通過可能な面積率 $\left(A_{x}, A_{y}\right)$ を導入する. 詳細は文献16)-19)を参照されたい.

掃流砂の移動方向算定時に重要となる $x$ よびy方向の 底面近傍流速 $\left(u_{b}, v_{b}\right)$ については，港湾内渦流に伴うエク マン層の発達》を考慮し, 河川流でよく用いられる次式 に示される水深平均流れの流線の曲率より算定した ${ }^{20}$.

$$
\begin{gathered}
u_{b}=u_{b s} \cos \alpha_{s}-v_{b s} \sin \alpha_{s} \\
v_{b}=u_{b s} \sin \alpha_{s}+v_{b s} \cos \alpha_{s} \\
u_{b s}=8.5 u_{*} \\
v_{b s}=-N_{*} \frac{h}{r} u_{b s} \\
\frac{1}{r}=-\frac{u\left(u \frac{\partial v}{\partial x}-v \frac{\partial u}{\partial x}\right)+v\left(u \frac{\partial v}{\partial y}-v \frac{\partial u}{\partial y}\right)}{\left(u^{2}+v^{2}\right)^{3 / 2}}
\end{gathered}
$$

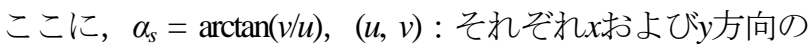
水深平均流速, $u_{*}$ : 摩擦速度, $h:$ 水深, $r$ : 水深平均流 れの流線の曲率である. 摩擦速度 $u$ についてはマニング 則より算定し， $N_{*}$ については7.0を用いた20).

\section{（2）地形変化モデルの基礎方程式}

デカルト座標系におけるFAVOR法を導入した流砂の 連続式および浮遊砂輸送方程式は以下のように表せる. ここで本研究では，一様砂のみを対象としている.

$$
\begin{aligned}
& \frac{\partial z_{B}}{\partial t}+\frac{1}{V(1-\lambda)}\left[\frac{\partial\left(A_{x} q_{B x}\right)}{\partial x}+\frac{\partial\left(A_{y} q_{B y}\right)}{\partial y}+V\left(q_{s u}-w_{f} c_{b}\right)\right]=0 \text { (6) } \\
& \frac{\partial c h}{\partial t}+\frac{1}{V}\left\{\frac{\partial\left(A_{x} c u h\right)}{\partial x}+\frac{\partial\left(A_{y} c v h\right)}{\partial y}\right\} \\
& =\frac{1}{V}\left[\frac{\partial}{\partial x}\left(A_{x} K_{h} \frac{\partial c h}{\partial x}\right)+\frac{\partial}{\partial y}\left(A_{y} K_{h} \frac{\partial c h}{\partial y}\right)\right]+q_{s u}-w_{f} c_{b}
\end{aligned}
$$

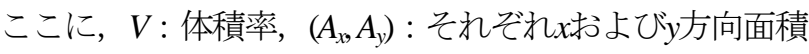
率, $z_{B}$ : 基準面からの底面高さ, $\lambda$ : 空隙率 $(=0.4),\left(q_{B v}\right.$, $\left.q_{B y}\right)$ : それぞれxおよびy方向単位幅掃流砂量, $q_{s u}$ : 単位 面積当たりの浮遊砂浮上量, $w_{f}$ : 沈降速度, $c_{b}$ : 底面近 傍浮遊砂濃度, $c$ : 水深平均の浮遊砂濃度, $K_{h}$ : 水平方 向拡散係数である. 沈降速度 $w_{f}$ は Rubey式より求めた.

単位幅掃流砂量 $q_{B}$ の算定には, 河川流で実績の高い芦 田・道上式 ${ }^{21)}$ を採用した。 芦田・道上式は津波による地 形変化一の適用から，その妥当性が確認されている ${ }^{14}$.

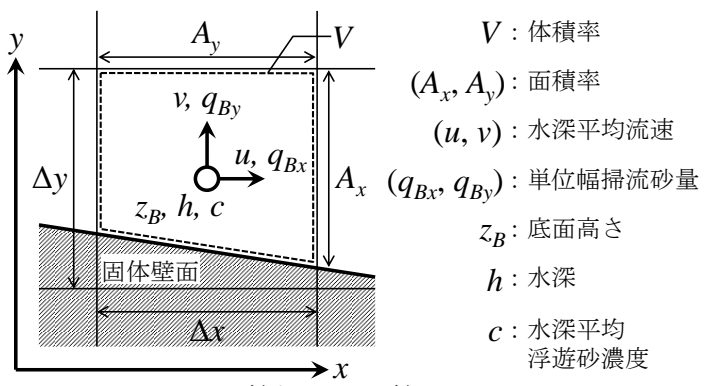

図-1 計算格子と計算諸量の配置

$$
\frac{q_{B}}{\sqrt{s g d^{3}}}=17 \tau_{* e}^{3 / 2}\left(1-\frac{K_{c} \tau_{* c}}{\tau_{*}}\right)\left(1-\sqrt{\frac{K_{c} \tau_{* c}}{\tau_{*}}}\right)
$$

ここに, $s$ : 砂の水中比重, $g$ : 重力加速度, $d$ : 砂の粒 径, $\tau_{w_{e}}$ : 無次元有効掃流力, $\tau_{*}$ : 無次元限界掃流力, $\tau_{*}$ : 無次元掃流力, $K_{c}$ : 底面の局所勾配の影響による補 正関数 ${ }^{20)}$ である. $\tau_{*}$ は岩垣式 ${ }^{22)}$ より算定し，また，河床 波が無い場合を想定して $\tau_{*_{e}}=\tau$ * とした. 各方向の単位幅 掃流砂量 $\left(q_{B v} q_{B y}\right)$ は, 芦田ら ${ }^{200}$ の方法により求めた.

津波に伴う浮遊砂浮上量 $q_{\mathrm{su}}$ の算定式については, 従来 より幾つかの式が提案されている2,14)ものの，その予測 精度には未だ問題が残されている. そのため, 本研究で は河川流で実績の高いItakura and Kishi式23)を採用した。

$$
\begin{gathered}
q_{s u}=K\left(\alpha_{*} \frac{\rho_{s}-\rho}{\rho_{s}} \frac{g d}{u_{*}} \Omega-w_{f}\right) \\
\Omega=\frac{\tau_{*}}{B_{*}} \frac{\int_{\alpha^{\prime}}^{\infty} \xi \frac{1}{\sqrt{\pi}} \exp \left(-\xi^{2}\right) d \xi}{\int_{\alpha^{\prime}}^{\infty} \frac{1}{\sqrt{\pi}} \exp \left(-\xi^{2}\right) d \xi}+\frac{\tau_{*}}{B_{*} \eta_{0}}-1
\end{gathered}
$$

ここに, $\alpha^{\prime}=B \tau_{*}-1 / \eta_{0}, \quad \eta_{0}=0.5, \quad \alpha_{*}=0.14, \quad K=0.008, \quad B_{*}=$ $0.143, \rho_{s}$ : 浮遊砂の密度, $\rho$ : 水の密度である.

浮遊砂の鉛直方向濃度分布については，藤井ら ${ }^{14)}$ と同 様, 指数型の分布式を採用した. 従って, 式(6)および 式(7)中に示される底面近傍浮遊砂濃度 $c_{b}$ は次式で表せる

$$
c_{b}=\frac{\beta}{1-\exp (-\beta)} c, \quad \beta=\frac{w_{f} h}{K_{z}}
$$

ここに, $K_{z}$ : 鉛直方向拡散係数 $(=\kappa u$ h/6)である.

\section{(3) 基礎方程式の差分化}

本数値モデルでは，図-1に示寸ように，計算格子にレ ギュラー格子を採用した．また，浅水流方程式の移流項， 流砂の連続式(6)における空間微分項, および浮遊砂輸 送方程式(7)の移流項の差分化に，5次精度WENO法 ${ }^{11,13,18 \text {, }}$ 19)を適用した。 レギュラー格子では格子界面上で流速が 定義されないため，WENO法適用の際，格子中央点で Lax-Friedrich分離を用いた. また, 浅水流方程式の圧力項 には6次精度中央差分を, 粘性項・拡散項には4次精度中 央差分を適用した。時間積分については, 浅水流方程式 および浮遊砂輸送方程式(7)に3次精度TVD Runge-Kutta法 を，流砂の連続式(6)に1次精度Euler法を適用した。詳細 については参考文献18),19)を参照されたい。 


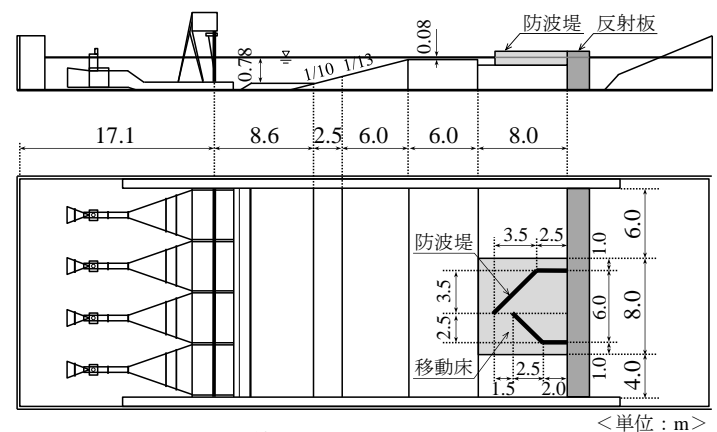

図-2 藤井ら ${ }^{14}$ による大型平面水槽の概略図

表-1 藤井ら ${ }^{14)}$ の実験を対象とした計算条件

\begin{tabular}{c|c}
\hline 計算時間間隔 $\Delta t(\mathrm{sec})$ & 0.02 \\
\hline 計算格子間隔 $\Delta x, \Delta y(\mathrm{~m})$ & 0.10 \\
\hline マニング粗度係数 $n\left(\mathrm{~s} / \mathrm{m}^{1 / 3}\right)$ & 0.012 \\
\hline 浮遊砂水平方向拡散係数 $K_{h}\left(\mathrm{~m}^{2} / \mathrm{s}\right)$ & 0.0001 \\
\hline
\end{tabular}

\section{3. 津波による地形変化に関する水理模型実験を 対象とした数値モデルの妥当性の検証}

\section{(1) 水理模型実験の概要と計算条件}

本研究では，藤井ら ${ }^{14}$ により実施された縮尺 $1 / 100$ の港 湾模型（防波堤厚さ0.15 m）を有する大型平面水槽での 水理模型実験を対象に, 数值モデルの妥当性を検証した. 図-2に大型平面水槽の概略図 ${ }^{14)}$ を示す。防波堤と護岸の 高さは，津波が越流しない高さとなっている．実験では， 周期60秒の半周期分，片振幅 $0.06 \mathrm{~m}$ 津波条件において, 流況のみを計測する固定床実験，および中央粒径 $d=0.08$ mmの砂を用いた移動床実験が行われている.

計算条件を表-1に示寸. 浮遊砂の水平方向拡散係数 $K_{h}$ 以外，固定床・移動床とも同様の条件とした．格子間隔 を0.10 mと比較的粗く設定しており，FAVOR法を用いな ければ防波堤形状（厚さ $0.15 \mathrm{~m}$ ）を表現できないことが 分かる．境界条件として沖境界では津波水位を与え，壁 面ではSlip条件とした．また，本研究で採用したWENO 法の有効性を確認寸るため, 浅水流方程式の移流項に1 次精度風上差分法を用いた計算との比較も行った.

\section{(2) 固定床実験における実験結果と計算結果との比較}

図-3はそれぞれ(a)藤井ら ${ }^{14}$ による実験結果，(b)WENO 法による計算結果，および(c)1次精度風上差分法による 計算結果の流速ベクトルを示したものである．左図が押 波時（30秒後），右図が引波時（50秒後）を示している， まず，押波時（左図）を見ると，両計算結果とも実験同 様，防波堤先端での剥離流，および縮流に伴う港内流入 時の流れの加速を良好に再現できている．また，港内で の渦流中心位置も実験值とほぼ一致している．WENO法 と1次精度風上差分法を比較すると，WENO法は港内で の渦流流速を大きく再現している，これは，WENO法で は1次精度風上差分法に比べ，数值粘性が抑えられたた
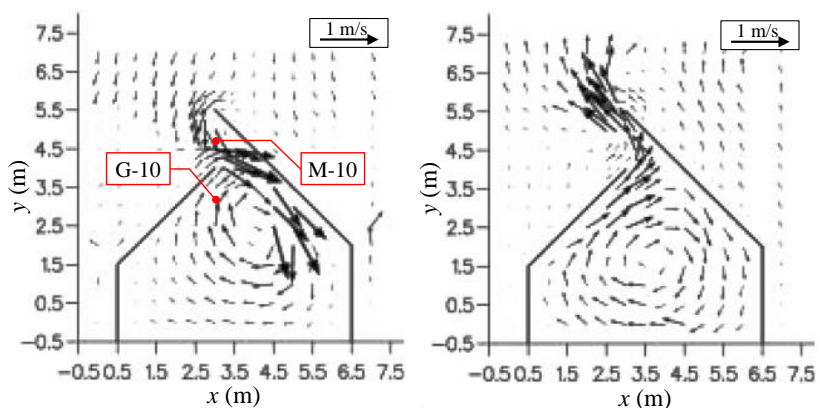

(a) 藤井らに ${ }^{14)}$ よる実験結果
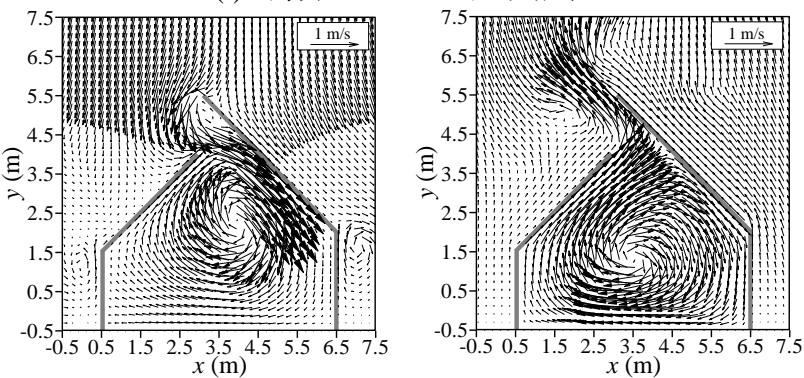

(b) WENO 法による計算結果
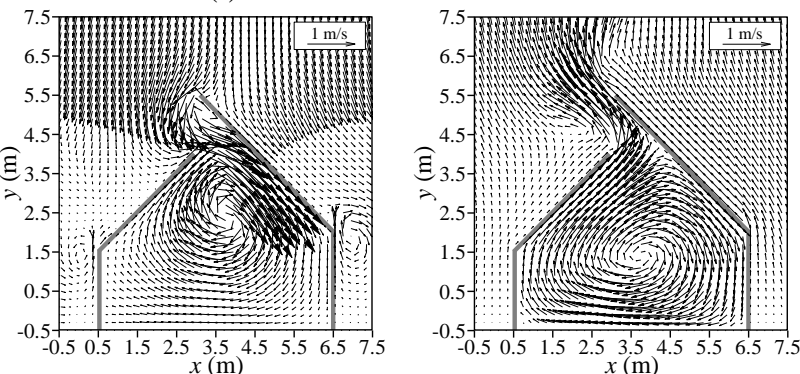

(c) 1 次精度風上差分法による計算結果

図-3 流速べクトルの比較 (左 : 30 秒後, 右 : 50秒後)

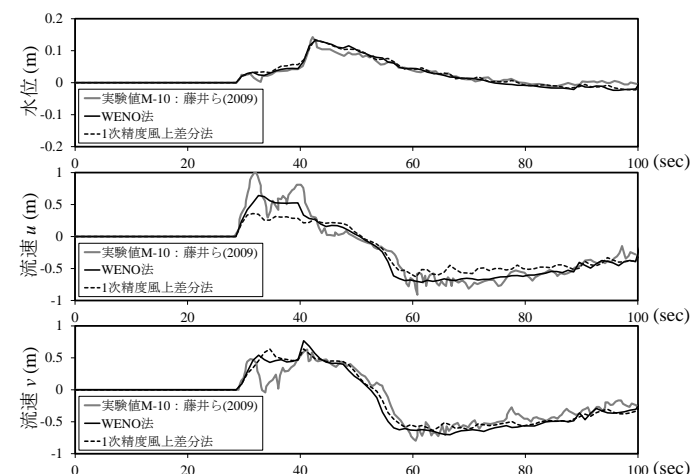

(a) M-10 地点

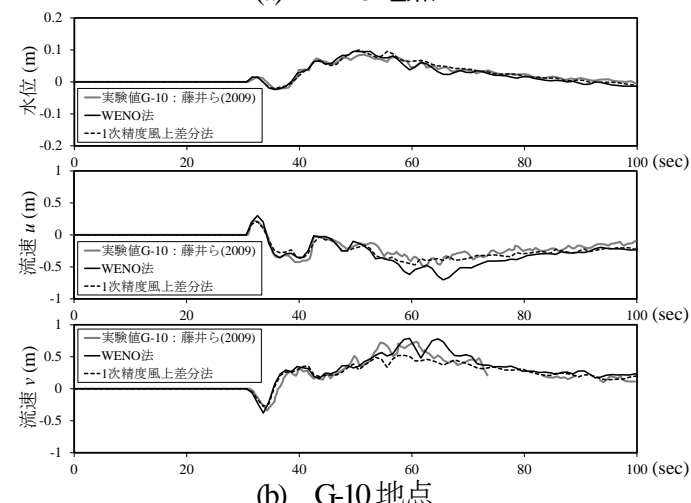

図-4 水位・流速波形の比較

めと考えられる．次に，引波時（右図）を見ると，両計 算結果は港内での渦流および港口から流出する高速流を 


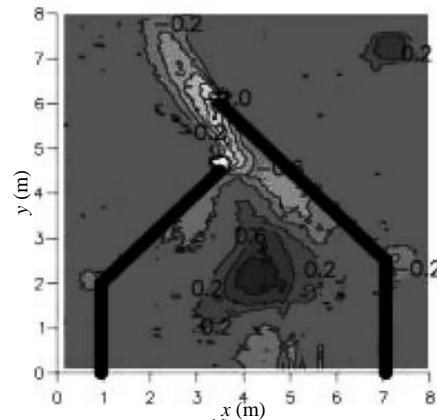

(a) 藤井ら ${ }^{14)}$ による実験結果

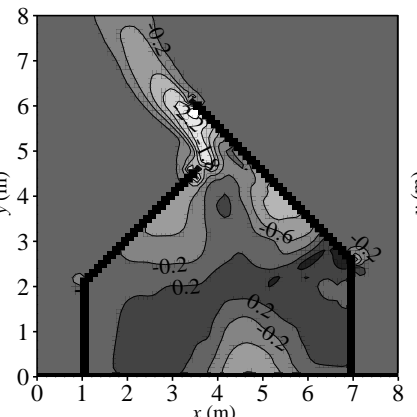

(b) WENO法 $\left(N_{*}=0.0\right)$

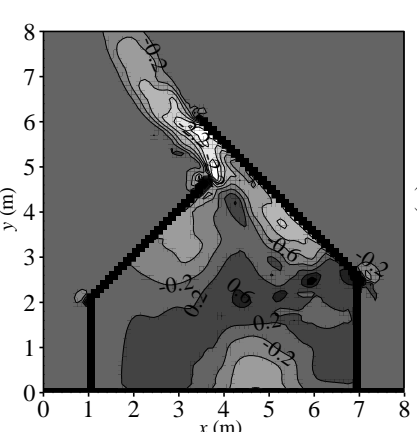

(c) WENO 法 $\left(N_{*}=7.0\right)$

図-5 移動床実験における地形変化量の比較

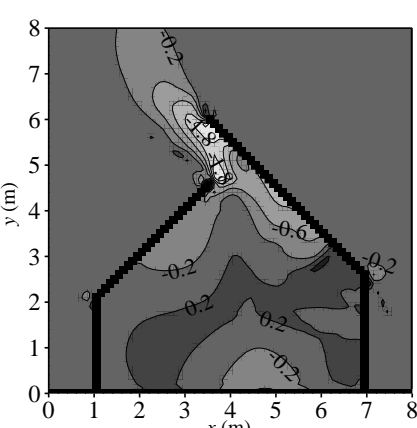

（d） 1 次精度風上 $\left(N_{*}=7.0\right)$

実験同様に再現できている. 両計算結果を比較すると, 押波時同様，WENO法は港内の渦流流速を，港内中央を 中心に大きく再現している．また，港口から流出寸る高 速流を見ると, WENO法では1次精度風上差分法に比べ, 流れの拡散傾向が若干抑えられている様子が分かる.

図-4は，図-3(a)左図に示される(a)M-10地点および(b)G10地点における水位・流速波形の比較を示している．図 より，水位については両計算結果とも良好に実験值と一 致している. 一方, 流速に関し, 実験では点計測值であ るため, 水深平均流速である計算結果との正確な比較は 難しい. しかしながら，両計算結果とも概飞実験值と一 致していることが分かる．両計算結果を比較すると, 港 口部の洗掘に大きな影響を与えるM-10での流速 $に$ に関し， WENO法では1次精度風上差分法よりも，押波時および 引波時における最大流速を大きく再現している.

\section{(3) 移動床実験における実験結果と計算結果との比較}

図一5はそれぞれ移動床実験における(a)藤井ら ${ }^{14} に$ にる 実験結果と，(b)式(4)における $N_{*}=0.0$ としたWENO法，(c) WENO法 $\left(N_{*}=7.0\right)$ および(d)1次精度風上差分法 $\left(N_{*}=7.0\right)$ の計算結果を示している. まず, 港内中央の堆積に着目 すると, 図-5(b)のN*=0.0としたWENO法では, その堆積 を再現できていないことが分かる，一方，図-5(c)で $N_{*}=$ 7.0 とすることにより, 実験值程ではないもののその堆 積傾向が改善されている. しかしながら, 図-5(d)の1次 精度風上差分法では, $N_{*}=7.0$ としても改善されていない. また，港口から港外にかけての侵食に着目寸ると，図一 $\mathbf{5}(\mathrm{d})$ の) 次精度風上差分法では実験值に比べて侵食量が小 さく, 侵食範囲も拡散傾向にある. 一方, 図-5(b)(c)の WENO法では量・範囲とも実験值と良好に一致している.

以上より，実験室規模の現象に対し，WENO法を用い た本数值モデルの妥当性が示された.

\section{2011年東北地方太平洋沖地震津波による宮城県 名取市閖上漁港の地形変化に関する数值計算}

\section{(1) 闒上漁港の概要}

閖上漁港は，宮城県名取市名取川右岸側に位置する第

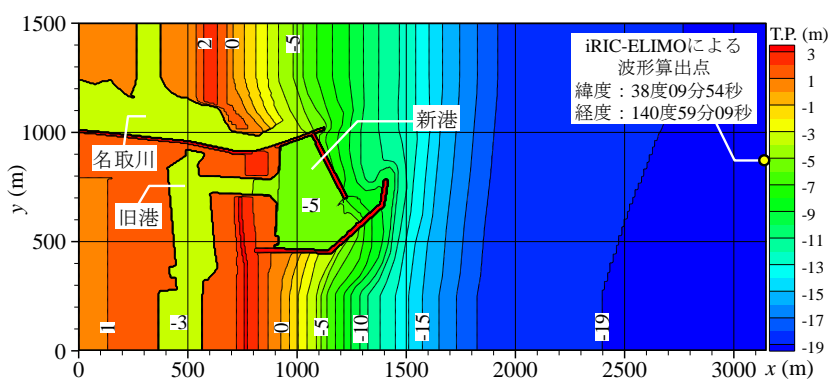

図-6 閖上漁港の概形と本数值モデルによる計算領域

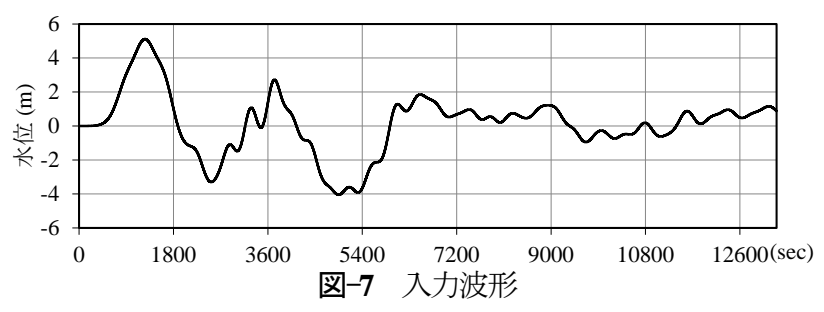

1種漁港である．図-6に漁港の概形を示寸，闒上漁港は， 2011年3月11日に発生した東北地方太平洋沖地震津波に より甚大な被害を受けた．被災後，松原ら ${ }^{15} に よ り$ 漁港 内の地形変化に関する深浅測量が実施されている. 本研 究では，この閖上漁港を対象に，現地スケールにおける 本数值モデルの適用性を検証する.

\section{（2）入力波形の作成と計算条件}

本研究では, 図-6に示される領域を対象に本数值モデ ルを適用した，そのため，沖境界での入力波形が必要と なる.ここでは，iRIC-ELIMO ${ }^{12)}$ を用いて波源からの津波 伝搬計算を行い，図一比示される波形算出点で入力波形 を作成した. 地形データには日本海洋データセンター ${ }^{24}$

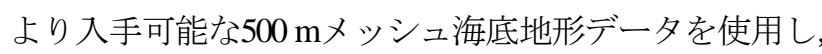
断層モデルには国土地理院 ${ }^{25}$ より報告されている值を使 用した．作成した入力波形を図-7に示す.

図-6を対象とした数值計算では, 被災前の初期地形と して, 港湾周辺の地形を田中ら ${ }^{20}$ の論文を参考に作成し, 港湾内については被災前の初期地形が不明であったため, 計画水深より旧港をT.P. $-3 \mathrm{~m}$, 新港をT.P. -5 mに設定した. 格子間隔は $5 \mathrm{~m}$ と, 粗度係数は $n=0.03$ で一様とした。 また, 砂粒径を $d=0.55 \mathrm{~mm}^{20}$ とし, 図-7の入力波形を沖 境界で軸方向に一様に与えた. 


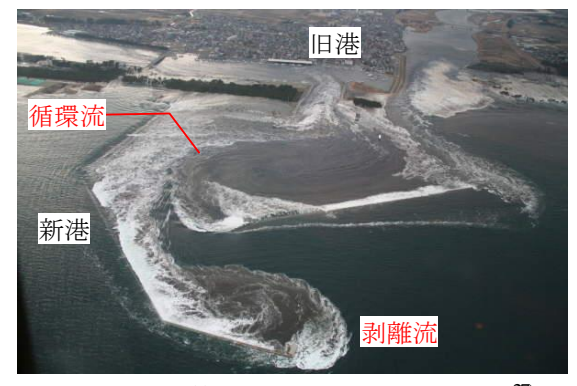

図-8 津波襲来時の閖上漁港内流況 ${ }^{27)}$
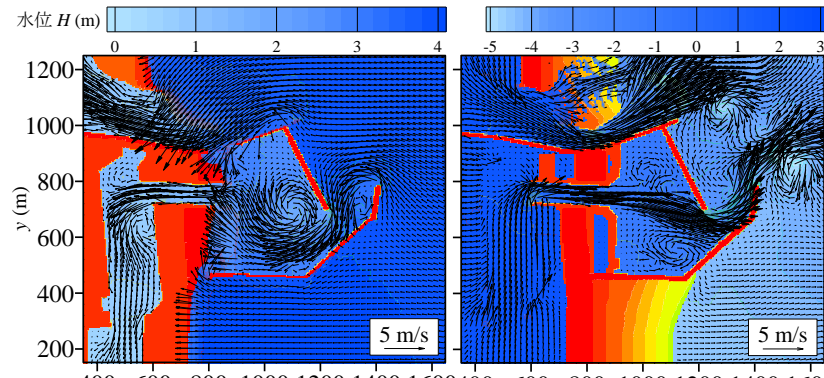

40060080010001200140016004006008001000120014001600 (a) 960 秒後（押波時）

(b) 2640 秒後（引波時）

図-9＼cjkstart計算結果による流速ベクトル

\section{(3) 計算結果および考察}

まず，図-8は津波襲来時における閖上漁港内の流況を 示したものである27. 防波堤先端では剥離流が，新港内 では時計回りの循環流が形成されている様子が分かる.

数值計算により得られた流況として，図-9に(a)計算開 始から960秒後（押波時），(b)2640秒後（引波時）の流 速ベクトルをそれぞれ示寸．図-8および図-9(a) との比較 より，定性的にではあるが，計算結果は防波堤先端にお ける剥離流および新港内における循環流を再現できてい る．また，図-9(b)からは，引波時に旧港と新港を結ぶ狭 窄部から新港港口部に向けて, 縮流に伴う直線的な高速 流が発生している様子が分かる.

図-10はそれぞれ(a)松原ら ${ }^{15}$ による深浅測量結果，(b) 計算結果（13260秒後）による地盤高コンターを示して いる. 図より，計算結果は新港港口部の局所洗掘および 北端での土砂堆積を十分再現できていないものの，旧港 と新港を繋ぐ狭窄部の洗掘は再現できている，また，そ の最深地盤高も，実測・計算ともにT.P.-13 m 定量的に 一致している. この狭窄部の洗掘は, 図-9(b)に示される 引波時の高速流によって引き起こされたものである.

新港港口部の局所洗掘が再現できなかった原因として, 非線形長波方程式に基づく本数值モデルでは構造物周辺 の3次元的流況を再現できないことにある. 図-9(b)から 分かるように，引波時には狭窄部から新港防波堤に向け て直線的に流れが衝突している．流れが構造物に衝突す る時, 従来の研究8) で指摘されている様に, 構造物前面 では流れが底面に潜り込み, 底面付近では構造物から離 れる流れが生じ，馬蹄形渦が形成されていた可能性があ る. その様な流況は本数值モデルでは再現できず，結果， 港口での局所洗掘を再現できなかったものと考えられる.

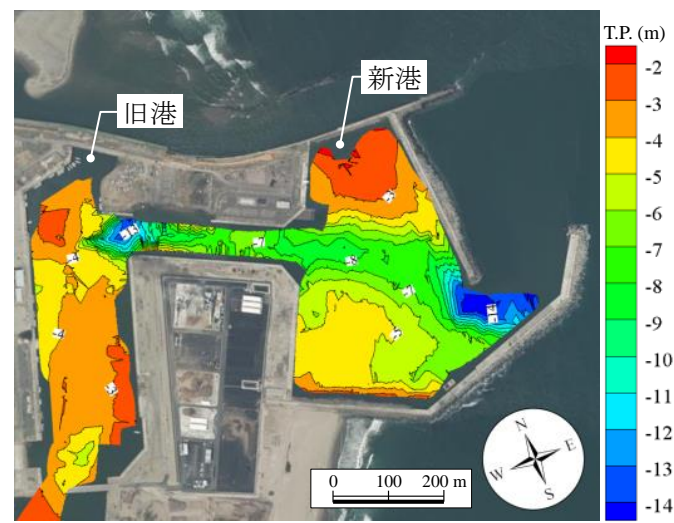

(a) 松原ら ${ }^{15}$ による深浅測量結果

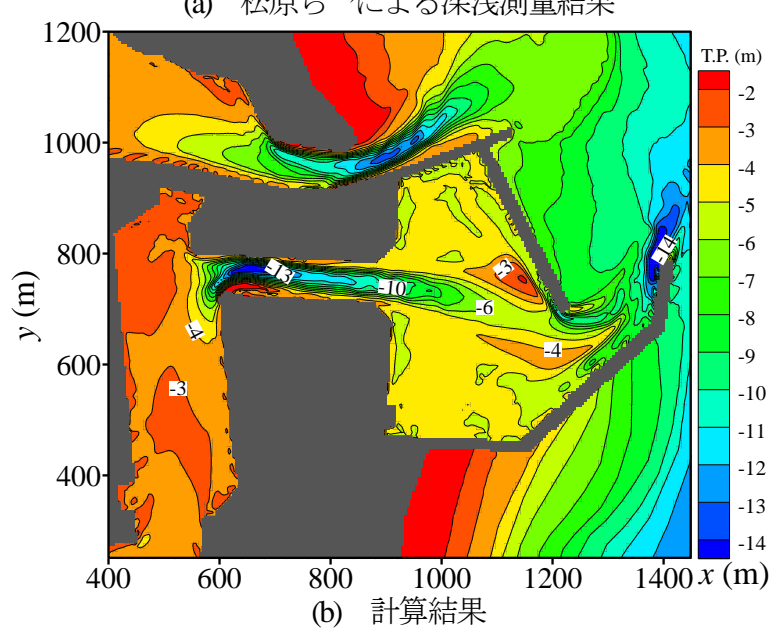

図-10 地盤高コンターの比較

一方，新港北端での土砂堆積の不一致については，モデ ル上の問題のみならず，初期地形（図-6）が被災前実地 形と異なっていた可能性もあり，今後の検討課題である。

以上より, 本数值モデルは現地スケールの地形変化に ついて, 3次元的流況の発達寸る領域一の適用は困難で あるものの, 狭窄部の洗掘など, 縮流に伴う地形変化に ついては再現可能であることが示された.

\section{5. まとめ}

本研究では, 津波による港湾内地形変化の高精度予測 を目的とし，5次精度WENO法を用いた数值モデルを提 案するとともに, 水理模型実験および現地スケールの現 象を対象とした数值計算からモデルの妥当性を検証した. 以下に, 本研究で得られた成果を述べる.

- 固定床実験との比較から, 粗い格子間隔でも, 本数 值モデルは津波に伴う港湾内外の流況を良好に再現 できることが分かった.

- 移動床実験との比較から, 本数值モデルは縮流に伴 う港口部周辺の地形変化を良好に再現できることが 分かった. また，港内の土砂堆積については，掃流 砂の移動方向を示寸底面近傍流速を考慮することで, 若干ではあるがその堆積傾向を改善できた。

- 閖上漁港を対象とした現地スケールの数值計算から, 
本数值モデルは3次元的な流況の発達する領域への 適用は困難であるものの，縮流による地形変化につ いては再現可能であることが分かった。

\section{参考文献}

1）藤井直樹, 大森政則, 高尾誠, 金山進, 大谷英夫: 津 波による海底地形変化に関する研究, 海岸工学論文 集，第 45 巻, pp.376-380, 1998.

2) 高橋智幸, 首藤信夫, 今村文彦, 浅井大輔: 掃流砂 層・浮遊砂層間の交換砂量を考慮した津波移動床モ デルの開発，海岸工学論文集，第 46 巻，pp.606-610, 1999.

3）西畑剛, 田島芳満, 森屋陽一, 関本恒浩: 津波による 地形変化の検証-2004 年スマトラ沖地震津波スリラン カ・キリンダ港-, 海岸工学論文集, 第 52 巻, pp.1386-1390, 2005.

4) Li, L., Qiu, Q., and Huang, Z.: Numerical modeling of the morphological change in Lhok Nga, west Banda Aceh, during the 2004 Indian Ocean tsunami: understanding tsunami deposits using forward modeling method, Natural Hazards, 64, pp.1549-1574, 2012.

5) Xbeach Open Source Community: http://oss.deltares.nl/ web/xbeach/, 参照 2016-05-26.

6) Sugawara, D., Goto, K., and Imamura, F.: Sediment transport due to the 2011 Tohoku-oki tsunami at Sendai: Results from numerical modeling, Marine Geology, 358, pp.18-37, 2014.

7）木原 直人，松山昌史: 津波による土砂移動問題に対す る静水圧 3 次元津波解析システム C-HYDRO3D Tsunami の適用性の検討一インド洋大津波による Kirinda 港周辺における土砂移動解析一, 電力中央研究所報 告, N09004, 2010.

8) 内田龍彦，福岡捷二: 底面流速解析法を用いた津波に よる構造物周りの三次元流れと局所洗掘解析，土木 学会論文集 B2(海岸工学), Vol. 69, No. 2, pp.I_271I_275, 2013.

9) Goto, C., Ogawa, Y., Shuto, N., and Imamura, F.: Numerical method of tsunami simulation with the leap-frog scheme (IUGG/IOC Time Project), IOC Manual, UNESCO, NO. 35, 1997.

10) Liu, P. L. F., Cho, Y., Briggs, M. J., Kanoglu, U., and Synolakis, C. E.: Runup of solitary waves on a circular island, J. Fluid Mech., 302, pp.259-285, 1995.

11) Shu, C.W.: High order Finite Difference and Finite Volume WENO Schemes and Discontinuous Galerkin Methods for CFD, NASA/CR2001-210865, ICASE Report No. 2001-11.

12) iRIC-ELIMO: http://i-ric.org/, 参照 2016-05-26.
13) Li, Y. and Raichlen, F.: Non-breaking and breaking solitary wave run-up, J. Fluid Mech., 456, pp.295-318, 2002.

14) 藤井直樹, 池野正明, 榊山勉, 松山昌史, 高尾誠, 向原健: 津波による港湾内の流況と地形変化に関する 実験およびその数值計算, 土木学会論文集 B2(海岸工 学), Vol. 65, No.1, pp.291-295, 2009.

15) 松原雄平, 黒岩正光, 涉谷容子, 市村康, 米村正三: 小型サイドスキャンソナーを用いた宮城県名取市閆 上漁港の東北地方太平洋沖地震による津波被害調查, 土木学会第 68 回年次学術講演会講演概要集, II-185, pp.369-370, 2013.

16) Hirt, C.W. and Sicilian, J.M.: A Porosity Technique for the Definition Obstacle in Rectangular Cell Meshes, Flow Science, Inc. Los Alamos, New Mexico, pp.450-469, 1985.

17) 黒岩正光，高田哲志，松原雄平: FAVOR 法を用いた 海浜流モデルの開発と海浜流場に与える計算格子と 渦動粘性係数の影響に関する一考察，海洋開発論文 集, 第 25 巻, pp.1239-1244, 2009.

18）梶川勇樹，檜谷治: WENO 法を用いた平面 2 次元浅水 流モデルの開発，土木学会論文集 B1(水工学), 第 69 巻, 4 号, pp.I_631-636, 2013.

19) Kajikawa, Y. and Hinokidani, O.: Numerical simulation of 2-D bed deformation in a slit sabo dam, Proc. of 35th IAHR World congress, USB, Theme C, A11452, 2013.

20) 芦田和男, 江頭進治, 劉炳義: 蛇行流路における流砂 の分級および河床変動に関する数值解析, 水工学論 文集，第 35 巻，pp.383-390, 1991 .

21）芦田和男，道上正規: 移動床流れの抵抗と掃流砂量に 関する基礎的研究，土木学会論文報告集，第 206 号， pp.59-69, 1972.

22) 岩垣雄一: 限界掃流力の流体力学的研究, 土木学会論 文集，第 41 号, pp.1-21, 1956.

23) Itakura, T. and Kishi, T.: Open channel flow with suspended sediments, J. of Hyd. Div., ASCE, Vol. 106, HY8, pp.1325-1343, 1980.

24) 日本海洋データセンター: http://www.jodc.go.jp/, 参照 2016-05-26.

25) 国土地理院: 平成 23 年（2011 年）東北地方太平洋沖 地震に伴う地殼変動と震源断層モデル, http://www. gsi.go.jp/cais/topic110422-index.html, 参照 2016-05-26.

26）田中茂信, 佐藤慎司, 小関賢次, 佐々木健一, 大谷 靖郎, 橋本新: 仙台湾南部海岸における構造物周辺の 土砂移動観測, 海岸工学論文集, 第 44 巻, pp.556560, 1997.

27) 宮城県名取市の閖上漁港入流入する津波 (海上保安庁 提供, 航空機 MH906 撮影) (2011 年 03 月 11 日): http:// www.agreenring.com/cgi/ciel/topics.cgi, 参照 2016-05-26.

(2016.3.16 受付)

\section{NUMERICAL SIMULATION OF TOPOGRAPHY CHANGE IN HARBOR DUE TO TSUNAMI USING HIGH ORDER WENO SCHEME}

\section{Yuki KAJIKAWA, Masamitsu KUROIWA, and Hisanari NAKAYAMA}

In this paper, a 2D numerical model using the high order WENO (Weighted Essenciallty NonOscillatory) scheme was proposed in order to predict a topography change in a harbor due to Tsunami. In this model, the FAVOR (Fractional Area/Volume Obstacle Representation) method was introduced into the governing equations. We applied the model to the small-scale experiment and the large-scale actual phenomenon in order to verify the validity of the model. Consequently, although the model was not able to reproduce local scouring around a breakwater where three dimensional flow was developed, it was clarified that the model can reproduce the topography change well by contracted flow. 